\section{Kontrollierte Beatmung}

Helga Peter

Marburg, Deutschland

\section{Synonyme}

Künstliche Beatmung

\section{Englischer Begriff}

artificial respiration

\section{Definition}

Vollständige künstliche Beatmung, bei der die Atmung von einem Respirator übernommen und von außen kontrolliert wird; die kontrollierte Beatmung ist nur in einem in sich geschlossenen Mensch-Maschine-System ohne Leckagen zuverlässig zu gewährleisten.

Siehe auch

- „Mechanische Ventilation“

- $>$ „IPPV“ 